\title{
セラミックス多孔体のイメージベースモデリングと均質化法による弾性解析
}

\author{
木村圭一 + 高野直樹* · 久保 太* $^{*}$ 小川秋水 $\cdot$ 河本 洋·座古 勝* \\ ファインセラミックス技術研究組合シナジーセラミックス研究所, 456-8587 名古屋市熱田区六野 2-4-1 \\ *大阪大学大学院工学研究科, 565-0871 大阪府吹田市山田丘 2-1
}

\section{Image-Based Modeling and Elastic Analysis of Porous Ceramics by the Homogenization Method}

\author{
Keiichi KIMURA, ${ }^{\dagger}$ Naoki TAKANO, ${ }^{*}$ Futoshi KUBO, ${ }^{*}$ Syusui OGAWA, \\ Hiroshi KAWAMOTO and Masaru ZAKO*
}

\author{
Synergy Ceramics Laboratory, Fine Ceramics Research Association, 2-4-1, Mutsuno, Atsuta-ku, Nagoya-shi 456-8587 \\ *Department of Manufacturing Science, Osaka University, 2-1, Yamada-oka, Suita-shi, Osaka 565-0871
}

\begin{abstract}
A three-dimensional elastic analysis system for porous ceramics has been built. In this system, three-dimensional morphology of pores is modeled using voxel (volume pixel) elements from digital images. Elastic analysis with this image-based finite element model is performed by the homogenization method. In order to investigate this analysis system, the elastic properties and behavior of porous $\mathrm{Al}_{2} \mathrm{O}_{3}$ with spherical pores on the order of $1 \%$ by volume were computed. Young's moduli obtained by the homogenization method were consistent with both experimental and theoretical values. Using computed moduli of elasticity, the state of local stress concentration around the pores in a bending test was calculated together with the global stress in the sample. It was found that the dependence of the bending strength upon porosity can be described by taking into account local stresses around the pores. The combination of image-based modeling and homogenization method is a useful way to analyze the mechanical behavior of porous ceramics especially with inhomogeneous morphology.

[Received December 25, 2001; Accepted March 25, 2002]
\end{abstract}

Key-words : Computational mechanics, Porous ceramics, Image-based modeling, Three-dimensional modeling, Finite element method, Homogenization method, Voxel element

\section{1. 緒言}

セラミックス多孔体は，污染物質の分離装置を始めとするエ ネルギー・環境関連機器に利用される材料として必要性が高 まっている．このような機器に使用される多孔体部材の弾性率 や強度は，その気孔形態に敏感である。したがって，多孔体か らなる部材の機械的特性を解析する場合, 気孔形態を取り入れ て解析することが理想である. しかし，気孔のモデリングが困 難であること, 解析対象となる気孔と部材の大きさが著しく異 なることから, 実現が困難であった．本研究は, 精密研削加工 技術を用いたイメージベースモデリングとマルチスケール解析 手法である均質化法を採用することによって, 微視的な不均質 性を有する部材の力学挙動を解析するシステムを構築すること を目的とする.

従来, 多孔体の力学特性は, 複合則によって, 理論的, また は経験的に気孔率と関連づけられ，多孔体の評価に用いられて きた1) 4). しかし, 複合則では気孔形態は考慮されないか, 極 めて単純なものに限定される. 実際に製造される多孔体の組織 は, 理論式で導出可能な単純な形態をとらない場合が多い. 気 孔の体積率が大きくなれば, 気孔の連結が生じ, 形態も変わる ため, 広い組成範囲にわたって単一の複合則は成立しない.

気孔の形態を反映した解析を行う方法として, 計算機を利用 して気孔形態のモデリングを行い, 有限要素法等の手法で数值 解析を行う方法が挙げられる.この方法は, 材料の組織形態を 代表する小さな領域（代表体積要素 : RVE）を抽出して, RVE に対する力学問題を解く方法であり, RVE 法と呼ばれ

\footnotetext{
†現在：新日本製鐵(株)技術開発本部先端技術研究所,

293-8511 千葉県富津市新富 20-1

Now with Advanced Technology Research Laboratories, Nippon Steel Corpration, 20-1, Shintomi, Futtsu-shi, Chiba 293-8511
}

る. RVE 法は, 多孔体の材料設計や多孔体構造物の解析手法 として, 計算機の発達と共に今後利用されていくものと予想さ れる.しかし，これまで材料分野での利用例はほとんどなく， 実際の材料を対象とした研究例も少ない。この理由として，モ デリングと計算の負荷が共に大きいことが挙げられる.

材料の組織形態のモデリングには, 仮想的な組織を発生させ る方法と実際の材料から形態情報を直接取得する方法がある. 前者の方法でセラミックス組織のモデリングを行い, 力学計算 を行った例として，粒子分散材5)や多孔体6)を対象にしたもの がある. 文献 6)に見られるように, この方法は, 第二相の体 積率や形態等を系統的に変化させてその挙動を調べるのに都合 が良い.しかし, 実際の複雑な組織形態を模擬するのは難し く, シミュレーション自体が研究対象になっている7).

一方，実験的に組織形態を得る手法として，組織画像からモ デリングを行う手法があり，イメージベースモデリングと呼ば れる. この例として, 繊維強化セメントの細孔構造の特徵を数 学的に解析し, 凍結感受性と比較した例がある ${ }^{8)}$.この例に見 られるように, イメージベースモデリングは, 計算機上で発生 させることが難しい複雑な組織形態を有する材料のモデリング 方法として有効である.

イメージベースモデリングで 3 次元モデルを得るために は, X 線 CT や研削加工により複数の 2 次元断面像をとり, こ れを計算機上で 3 次元に再構築する方法が取られる. 3 次元の イメージベースモデリングは, 医療分野で藏器や骨格のモデリ ングに多く用いられており，海綿骨のような多孔体を扱った例 もある ${ }^{9), 10)}$. セラミックス材料を対象とした例としては，モル タルと骨材で構成されるコンクリートのモデリングを行い，圧 縮に対する力学挙動を解析した例がある11).

一般にセラミックス多孔体の気孔の大きさは， $10^{2} \mu \mathrm{m}$ 以下 
にあるものが多く, 海綿骨やコンクリートの骨材と比較して小 さい，したがって，従来の研削加工や市販のX 線 CTによる データの取得が困難である. また, 気孔形態も複雑であり,こ れを再現するためには多くのデータ量を必要とする．従来の沉 用パーソナルコンピュターではモデリングと解析が困難であ り，広く材料研究者に利用されるに至っていない。

一方，部材として使用される多孔体の大きさは，気孔の大き さに対して非常に大きい。したがって，多孔体部材について， 単純に気孔の形態までモデリングを行うことは，計算規模が膨 大になることから，現実的に不可能である.

この問題を克服する試みが計算力学の分野で行なわれてお り，均質化法は有力な方法の一つである。均質化法は，1970 年代後半に考案された応用数学理論であり12),13)，1980年代か ら複合材料への工学的応用が検討され始めた方法である14). 均質化法では，解析対象の構造体（グローバルモデル）を，そ れに比べて十分小さな RVE（ローカルモデル）が周期的に積 み重なった集合体として扱い，RVEの平均化された物性值を 用いて構造体の数值解析を行う。線形力学問題では, RVEの 物性值は弾性定数であり, 均質化弾性定数 $\left(E^{\mathrm{H}}\right)$ と呼ばれる. 均質化弾性定数は，周期境界の下での自己平衡方程式から導出 される. 均質化法は, 構造体の巨視的な力学方程式とRVEの 微視的な力学方程式を, RVEの周期性を入れることによって 独立かつ数学的に連成させて解く手法である.

均質化法の利点は, 構造体の力学計算結果加 $\mathrm{RVE} へ$ の逆 計算が可能である点である.すなわち，構造体の任意の部分に 打ける局所的な応力を求めることが可能である. したがって, 均質化法は, 部材の解析に抢いて, 微視的な不均質性を反映し た解析を可能にする有用な力法である。しかし，均質化法の複 合材料への適用については, 計算力学の観点からの検討例は多 いが，実際の材料への適用例は多くない，規則的な構造を有す る FRP ${ }^{15)}$ や前述したコンクリートの解析 ${ }^{11)}$ に用いられた例は めるが，均質化法を様々な材料の解析により広く適用していく ためには，実験と計算の両面からの検討と利用する立場からの ニーズの掘り起こしが必要である. そのためには, 汎用のシス テムの構築が必要と考える.

本研究では，数十マイクロメートルの気孔を有するセラミッ クス多孔体の 3 次元気孔形態を実験的に取込み, 均質化法に よって弾性解析を行うシステムを構築した. システムの検証の ために，気孔率の低い単純な球状気孔を有するアルミナ多孔体 を用いて弾性解析を行い，実験值，理論值，有限要素法による 数值計算結果との比較を行った。 また，この手法の利用法の一 つとして, 気孔の存在による応力集中の状態を解析する手法を 提案した.

\section{2. 解析方法}

\section{1 システムの概要}

図 1 は，システムの概要を示す流れ図である。システムは大 きく分けてモデリング部と弾性解析部に分けられる.モデリン グ部は，3 次元気孔形態を取り込み，数值計算を行うための乇 デルを作成する部分である．ここでは，セラミックス多孔体の 微視領域のモデルでめるローカルモデルが作成される. 弾性解 析部では, ローカルモデルについて, 均質化法で均質化弾性定 数の算出を行う. また, 部材の有限要素モデルであるグローバ ルモデルについて，ローカルモデルをRVEとして，RVEの 均質化弾性定数を用い，弾性解析を行う. 次いで，算出された 歪值から，ローカルモデル内に発生する局所的応力を計算す る.グローバルモデルに対する弾性解析によって得られる大域

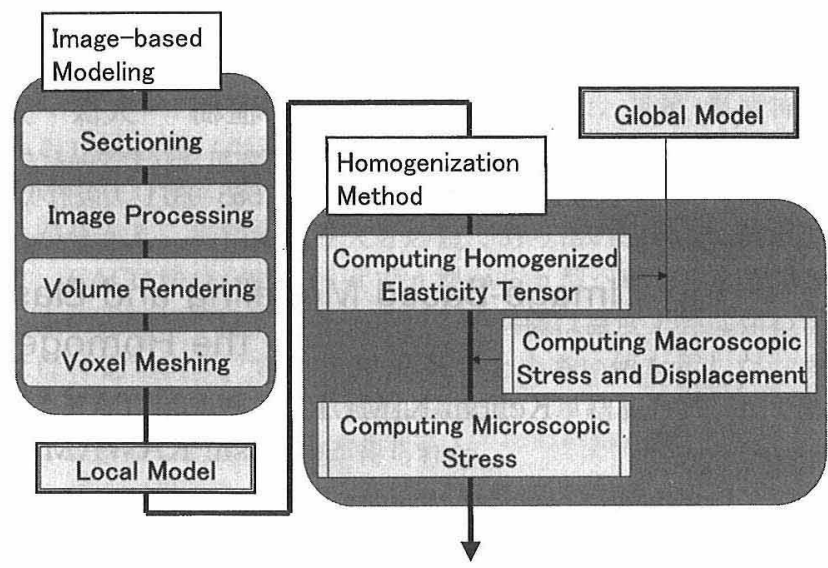

Fig. 1. Flow chart of the elastic analysis system with image-based modeling and the homogenization method.

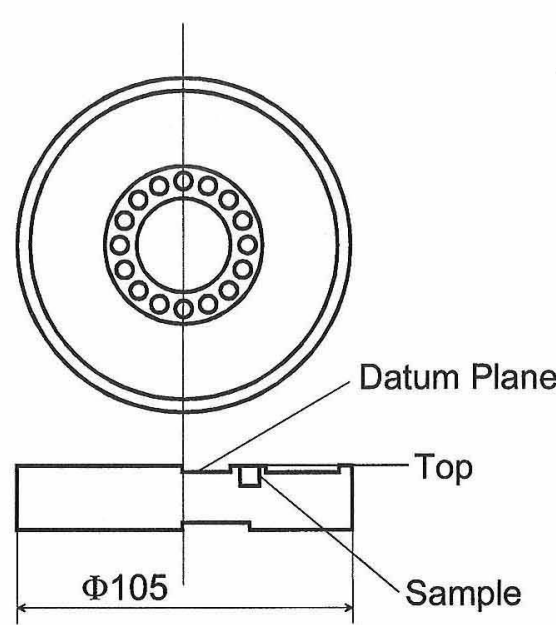

Fig. 2. Schematic illustration of the sample holder to grind 16 samples on the order of $1 \mu \mathrm{m}$.

的応力をグローバルストレス，ローカルモデルに対する解析で 得られる局所的応力をローカルストレスと呼ぶことにする。

モデリングと解析は, Intel 社のクロック周波数866 MHzの $\mathrm{CPU}\left(\right.$ Pentium $\left.^{\circledR} \mathrm{III}\right)$ と $2 \mathrm{~GB}$ のメモリーを搭載したパーソナ ルコンピュターを使用して行った.

\section{2 モデリング手法}

3 次元気孔形態のモデリングは，試料を一定間隔で研削する ことによって得た断面画像を，計算機上で立方体の直交固定要 素の集合体として 3 次元に再構成させることによって行っ た. 直交固定要素は，ボクセル（Voxel: volume pixelの略） と呼ばれる。

試料の画像は, 光学顕微鏡と CCD カメラを用いて取得し た．試料の研削は，図 2 に示した専用のアルミナ治具に試料を 埋め込み，ダイヤモンド砥粒を用いて，治具ごとラップ加工を 施すことにより行い，データの取得効率と研削精度の向上を 図った，治具を用いることによって，1 回の実験で16個の試料 のデータ取得が可能である. 本研究では，試料の気孔の大きさ から $2 \mu \mathrm{m}$ 間隔で研削を行った. 研削厚さは, 治具内に設けた 基準面と研削面の高さを触針式の厚さ測定器を用いて測定する ことで管理した，本研究では，深さ方向に合計51層の断面像 
を取得した。

画像は, 8 bit のグレースケール画像として取り込まれる. 取り込み時の画像解像度は約 $2 \mu \mathrm{m} / \mathrm{pixel}$, 画像の大きさは, 約 $1280 \times 960 \mu \mathrm{m}^{2}$ とした. この元画像から計算機に取り込む 二值化画像へ変換する課程で, いくつかの画像処理を行った. 始めに元画像の画像解像度を $1.00 \mu \mathrm{m} / \mathrm{pixel}$ に変換した. 次い で, 二值化を行う前処理として, 画像内の輝度補正と画像間の 輝度調整を行った. 次に, 画像間の位置調整を行い, この画像 からモデルとして抽出する領域を切出す加工を行った. 本研究 で抽出した領域の大きさは $280 \times 280 \mu \mathrm{m}^{2}$ とした. その後, 母 相を白, 気孔部分を黒とする二值化処理を行い, 更に研磨傷等 のノイズを除去したものをモデル用画像とした. 二值化した画

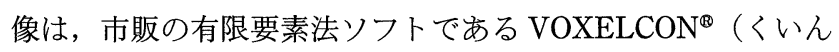
と製）を利用して計算機に取り込み, 更にボクセル要素への離 散化を行った. 本研究では, $280 \times 280 \times 100 \mu \mathrm{m}^{3}$ の領域を 140 $\times 140 \times 50$ 要素に分割した。したがってボクセルの大きさは $2 \mu \mathrm{m}$ 角である. ローカルモデルの大きさと要素数は, 計算機 の能力を考慮して決定した. モデルの抽出領域は, 実験で得ら れた気孔率にほぼ等しくなる部分を選んだ。

\section{3 弾性解析手法}

弾性解析部では, 上記のようにして得たローカルモデルを代 表体積要素 (RVE) として, 均質化法で弾性解析を行う. 均 質化理論の定式化, 及び本研究で用いた均質化法プログラムの 詳細は文献 5)に示されている.

2.2節に示した方法にて, ボクセル要素で離散化した 3 次元 モデルデータは, 専用のデータコンバータを介して均質化法プ ログラムに取り込まれる.

均質化法の計算手順は下記のようにして行う. 始めに RVE 9均質化弾性定数 $\left(E^{\mathrm{H}}\right)$ を求める. 均質化弾性定数は, 3 次 元の弾性テンソルの形で得られる. 均質化弾性定数が, 直交異 方性を有する場合は, これを用いてヤング率やポアソン比等の 工学定数を算出できる. 次に, 任意の形状のグローバルモデル について, ローカルモデルの均質化弾性定数を用いて力学計算 を行う.この計算には通常の有限要素法を用いる. 更に, 有限 要素法による計算で得られた任意の部分の歪值を用いて, 再度 RVEについて逆計算を行う。この結果, グローバルモデルの 任意の局所領域に扔けるローカルストレスが導出される。ロー カルストレスはボクセル要素の重心点で計算される.

本研究では, 実験と同じ, 高さ $3 \mathrm{~mm}$, 幅 $4 \mathrm{~mm}$, 長さ 40 $\mathrm{mm}$ の曲げ試験片（JIS R1601）を対象として計算を行った. 対称性から, 作成したグローバルモデルは, 試験片の $1 / 4$ 領 域の $3 \times 2 \times 20 \mathrm{~mm}^{3}$ の形状とした. 曲げ試験において支点とな る部分に当たる節点を高さ方向に拘束し, 対称面となる $3 \times 2$ $\mathrm{mm}^{3}$ の面, 及び $3 \times 20 \mathrm{~mm}^{2}$ の面上の節点に対し, それぞれ長 さ方向, 幅方向に拘束した上で, 荷重点に当たる節点に高さ方 向の線分布荷重を与え, グローバルモデルに対して有限要素法 で計算を行った. 次いで, グローバルモデルの計算結果で最も 引張応力が高くなる支点間表面近傍の局所領域のローカルスト レスを求めた. ローカルストレスは, ローカルモデル内の総数 約100万のボクセル要素にそれぞれ 1 点ずつ与えられる.

また, これとは別に, ローカルモデルの工学定数は, VOXELCON ${ }^{\circledR}$ 用い, 通常の有限要素法を用いても計算可能 である. 本研究では, 均質化弾性定数から求めたヤング率と有 限要素法で強制変位を与えて求めたヤング率の比較を行った. 有限要素法に扔ける拘束条件は, ローカルモデルの一面を一様 に強制変位させ，この面と平行な反対側の面を法線方向に拘束 し，更にこの面の中央部 1 点を完全拘束させるように与え
た. ヤング率は, この結果算出される强制変位をかけた面の反 力の総和から求めた.

\section{3. 実験方法}

\section{1 試料の作製方法}

解析システムの検証に用いる試料として, 気孔率 $10 \mathrm{vol} \%$ 以 下の球状気孔を有するアルミナ多孔体を作製した，原料は，純 度99.99\%のアルミナ粉末（大明化学工業製，TM-DAR）を用 いた。 また, 造孔剤として平均粒径 $20 \mu \mathrm{m}$ のアクリルビーズ （綜研化学製，MR-20G）を使用した. 0.500 mass\%から 3.00 mass\%をでの 4 種類の組成で秤量した粉体をエタノール中で 混練した後，エバポレターを用いて乾燥し，ふるい目 $250 \mu \mathrm{m}$ のふるいを通して混合粉体を作製した：この混合粉体を，金型 を用いて一軸成形し，更に $150 \mathrm{MPa}$ の圧力で静水圧成形する ことにより成形体を得た. 成形体の熱処理は, アクリルを消散 させる工程とアルミナ粉末を焼結させる工程の 2 段階で行っ た. 前者の熱処理は, 炬内に外気を供給しながら, 平均 $3^{\circ} \mathrm{C} / \mathrm{h}$ で昇温し， $540^{\circ} \mathrm{C} て ゙ 10 \mathrm{~h}$ 保持した後, $20^{\circ} \mathrm{C} / \mathrm{h}$ 以下の速さで降 温することにより行った．次に，アクリルを消散させた成形体

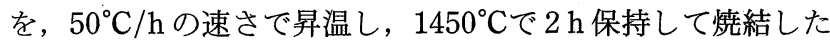
後, $50^{\circ} \mathrm{C} / \mathrm{h}$ 以下の速さで室温まで昵冷することにより多孔体 を得た.

焼成した多孔体の名称は，造孔剂が 0.500 mass\%の混合粉末 から作製した試料を Sample A, 1.00 mass\%, 2.00 mass\%，そ して3.00 mass\%の組成の粉末から作製した試料をそれぞれ Sample B, Sample C，及び Sample D とした。 また，基準試料 として，造孔剤を添加しない試料を同じ焼成条件で作製し，こ れを Sample S とした.

\section{2 測定方法}

計算結果と実験結果を比較するために, 試料の気孔率, ヤン グ率, ポアソン比, そして曲げ強度を測定した. 多孔体の気孔 率は, 重量と体積から算出した. アルミナの真密度は, 3.968 $\mathrm{g} / \mathrm{cm}^{3}$ とした ${ }^{16)}$ 。な, 基準となる Sample $\mathrm{S}$ の密度はアルキ メデス法により測定した.

試料のヤング率とポアソン比は, 超音波パルス法と圧縮試験 によって得た．超音波パルス法による測定は， $3 \times 4 \times 40 \mathrm{~mm}^{3}$ の曲げ試験片, または $4 \mathrm{~mm}$ 角の立方体試料を用いて行った。 長さ $3 \mathrm{~mm}$ ないし $4 \mathrm{~mm}$ の方向に超音波パルスを発信させ, 試 料端からの縱波と横波の反射時間を測定し，それらの速さから ヤング率とポアソン比を求めた．測定周波数は $20 \mathrm{MHz}$ であ る. 本試験で用いた試料は, 超音波パルス法で通常測定を行う 試料より小さいが，直径約 $15 \mathrm{~mm}$, 高さ $7 \sim 8 \mathrm{~mm}$ の試験片に 対する測定結果と比較して，有意な差がないことを確かめてい る. また，試料の切り出し方向によるヤング率とポアソン比の 異方性は認められなかった。

静的弾性率を求めるために, 压縮試験を補完的に行った. 本 試験に用いた試料の大きさは, $5 \times 7 \times 18 \mathrm{~mm}^{3}$ である. 試料の 長さ方向と平行に圧縮荷重を加えて, $7 \times 18 \mathrm{~mm}^{2}$ の面の中央 に生じる荷重方向の歪みとロードセルに加わる荷重值からヤン グ率を求めた. 四つの面のうち任意の平行な 2 面にゲージ間 隔 $1 \mathrm{~mm}$ の歪みゲージを貼り, 2 点の平均をとることによって 歪值を得た.

曲げ強度は 4 点曲げ試験によって得た。試料の大きさは, $3 \times 4 \times 40 \mathrm{~mm}^{3}$ であり, 幾何公差と表面粗さは JIS R 1601 に基 ゔいて試料の加工を行なった. 荷重の印加速さは, $0.5 \mathrm{~mm} /$ $\min$ とした. 


\section{4. 実験及び解析結果}

図 3 は， 1.00 mass\%の造孔剂を添加して作製した Sample B の光学顕微鏡写真で山る.緻密な母相内に球状の気孔が分散し た組織になっていることが分かる．図４に，造孔剤の添加量に 対する焼成後の試料の気孔率を示す，直線は，測定点を最小二 乗法で内外指したものである. 試料の気孔率は, 造孔剤の添加 量にほぼ比例している，造孔剂を添加しないで焼成した試料の 密度は， $3.960 \mathrm{~g} / \mathrm{cm}^{3}(99.8 \mathrm{vol} \%$ \%) であり，緻密と見なして

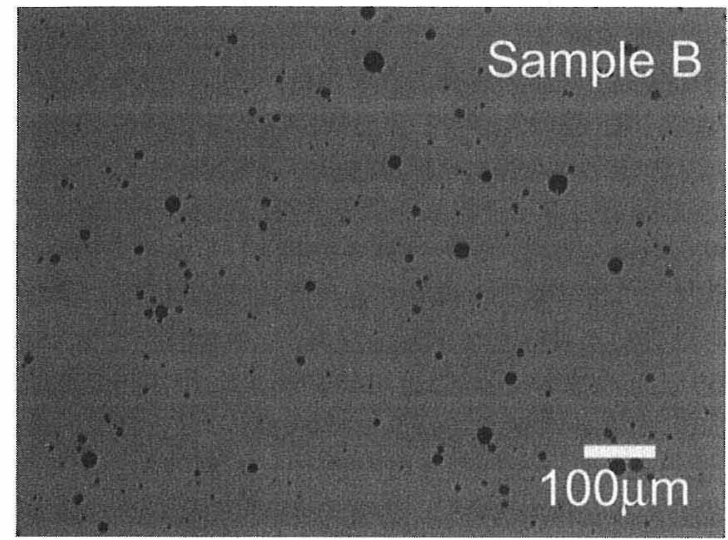

Fig. 3. Optical photograph of the porous $\mathrm{Al}_{2} \mathrm{O}_{3}$ sample sintered with 1.0 mass $\%$ acrylic beads.

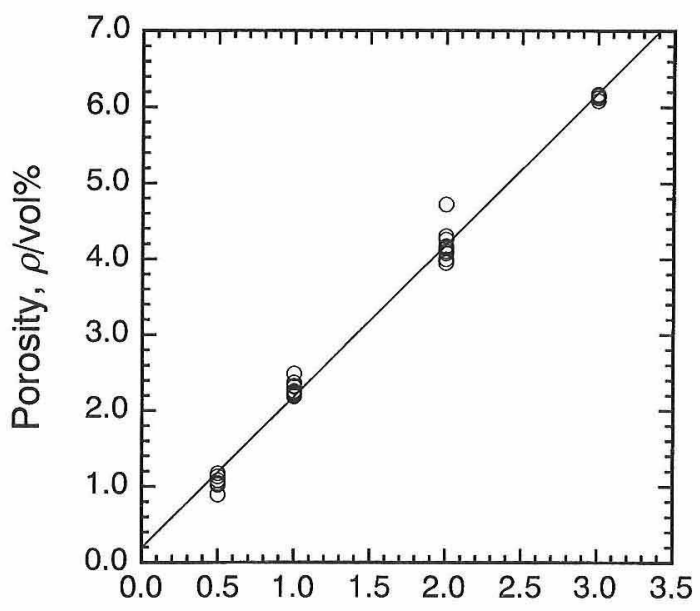

Amount of added acrylic beads, $m /$ mass $\%$

Fig. 4. Amount of added acrylic beads vs porosity of sintered $\mathrm{Al}_{2} \mathrm{O}_{3}$ ceramics.
よい. 図 4 の縦軸の切片は, 基準試料の気孔率にほぼ一致し ている。したがって，多孔体の母相の気孔率は，基準試料と同 じと考えられる．以上のことから，今回作製したアルミナ多孔 体は緻密な母相と球状の気孔で構成される系とみなして良いと 結論した。

表 1 に基準試料を含めた 5 種類の試料の気孔率, ヤング 率, ポアソン比, 及び 4 点曲げ強度の平均值を示した。 ヤン グ率とポアソン比は超音波パルス法による測定結果である。ヤ ング率は気孔率の増加と共に緩やかに減少している。これに対 して, 強度は, 気孔率が約 2 vol\%の Sample Bに括いて, 緻 密な Sample S の65\%の強度まで低下している。しかし, 気孔 率が大きくなるに従って, 気孔率に対する依存性は小さくなっ ている.

上記の組織と特性を有するアルミナ多孔体に対して，2 $2 \mu \mathrm{m}$ ずつラップ加工を行いながら, 組織画像を取得した. 図 5 は, この実験における研削の精度を表した図である，研削数に対す る総研削量を示すと共に，目標とする各層毎の研削量と実際の 研削量の差を示した．研削精度は $2 \mu \mathrm{m} \pm 0.1 \mu \mathrm{m}$ 以下に管理で きた。

図 6 (a)は，図 3 に示したSample B を研削して得た $2 \mu$ m間 隔の断面画像である. 試料表面の気孔の形が次第に变化してい く様子が分かる.これらの画像を二值化したものを図 6(b)に 示した.

このようにして得た二值化画像51枚に基づいて作成した Sample B の 3 次元ローカルモデルを図 7 に示す. サンプル名

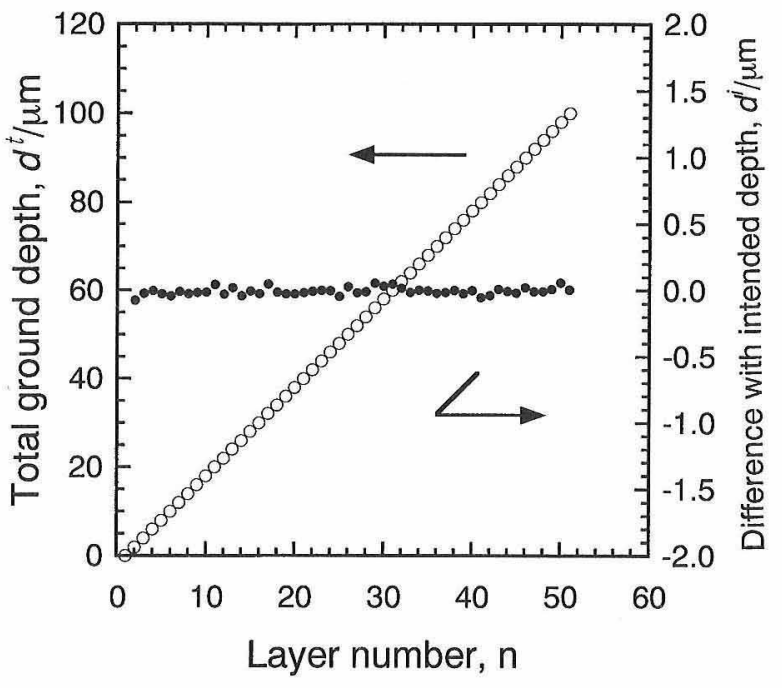

Fig. 5. Total depth and accuracy of grinding to obtain threedimensional morphology of pores.

Table 1. Average Properties of the Samples in This Study

\begin{tabular}{l|c|c|c|c|c}
\hline Sample code & S & A & B & C & D \\
\hline Amount of added acrylic beads /mass\% & 0.00 & 0.50 & 1.00 & 2.00 & 3.00 \\
\hline Porosity /vol\% & 0.208 & 1.06 & 2.28 & 4.19 & 6.14 \\
\hline Young's modulus /GPa & 404 & 393 & 387 & 369 & 351 \\
\hline Poisson's ratio & 0.238 & 0.238 & 0.238 & 0.236 & 0.236 \\
\hline Four-point bending strength $/ \mathrm{MPa}$ & 536 & 371 & 344 & 295 & 273 \\
\hline
\end{tabular}


(a)
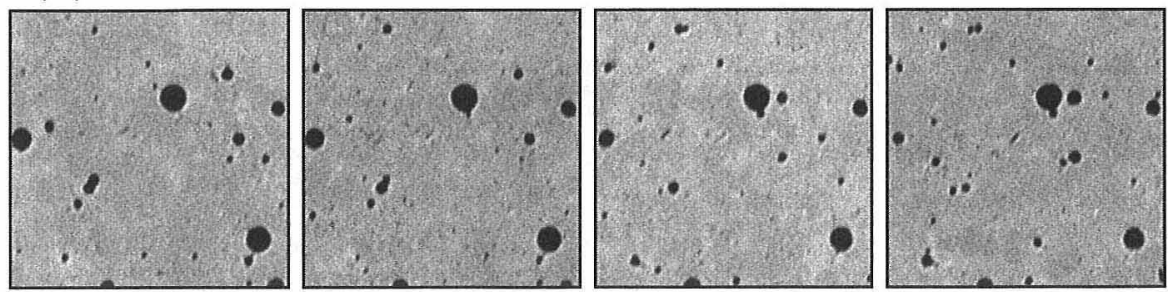

(b)
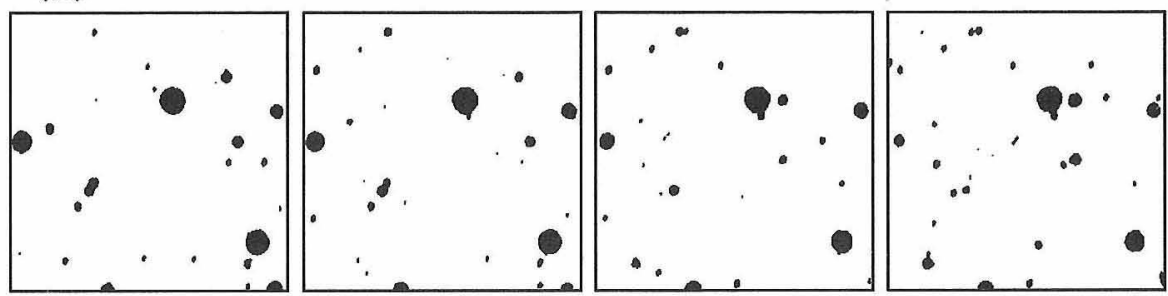

$100 \mu \mathrm{m}$

Fig. 6. Gray images processed before binarization (a) and their binary images (b) of the sample B sectioned at regular intervals of $2 \mu \mathrm{m}$.
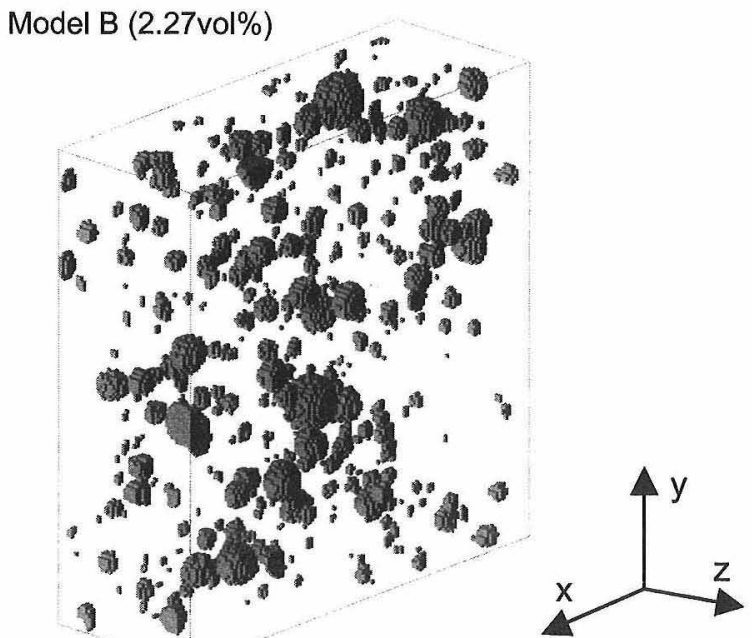

Fig. 7. Three-dimensional local model of the Sample B. The volume of the model is $280 \times 280 \times 100 \mu \mathrm{m}^{3}$. The model is represented by voxel elements with the size of $2 \times 2 \times 2 \mu \mathrm{m}^{3}$. Only the elements of pores are shown to visualize the inside of the model. The porosity is computed from the number of elements.

に対応させて，これを Model B とした。この図は, 気孔の内 部の様子と一つ一つの要素の大きさが分かるように, 気孔にあ たる要素のみ表記している. モデルの大きさは, $280 \times 280 \times$ $100 \mu \mathrm{m}^{3}(140 \times 140 \times 50$ 要素 $)$ である. また, 図に示した気孔 率は，モデルから算出したものである．滑らかな球面を表現す るには十分ではないが, 気孔分布の不均質さや連結の状態は表 現されている. 図 8 に,この他の 3 種類の気孔率を有する試 料のモデルを示した.

作成したローカルモデルについて, 均質化法を用いて均質化 弾性定数を計算した. 計算に使用したアルミナ母相のヤング率 とポアソン比は, Sample S の值からそれぞれ405 GPa, 0.240 とした。 また, 気孔の物性值は, アルミナ母相の $10^{-4}$ 倍とし た. 計算の結果得られた均質化弾性定数 $\left(E^{\mathrm{H}}\right)$ は下記のよう
になった。

$$
E_{\text {model A }}^{\mathrm{H}}=\left[\begin{array}{llllll}
E^{\mathrm{H}_{11}} & E^{\mathrm{H}}{ }_{12} & E^{\mathrm{H}_{13}} & E^{\mathrm{H}_{14}} & E^{\mathrm{H}} 15 & E^{\mathrm{H}} 16 \\
& E^{\mathrm{H}_{22}} & E^{\mathrm{H}_{23}} & E^{\mathrm{H}_{24}} & E^{\mathrm{H}_{25}} & E^{\mathrm{H}_{26}} \\
& & E^{\mathrm{H}_{33}} & E^{\mathrm{H}_{34}} & E^{\mathrm{H}_{35}} & E^{\mathrm{H}_{36}} \\
& & & E^{\mathrm{H}_{44}} & E^{\mathrm{H}_{45}} & E^{\mathrm{H}_{46}} \\
& \text { Sym. } & & & E^{\mathrm{H}_{55}} & E^{\mathrm{H}_{56}} \\
& & & & & E^{\mathrm{H}}
\end{array}\right]
$$

$=\left[\begin{array}{cccccc}467 & 147 & 146 & 0.0110 & -0.0673 & 0.0584 \\ & 468 & 146 & -0.00504 & -0.0335 & 0.0646 \\ & & 464 & 0.0493 & -0.0583 & 0.0100 \\ & & & 160 & 0.0204 & -0.0451 \\ & \text { Sym. } & & & 159 & 0.00958 \\ & & & & & 160\end{array}\right]$

$$
E_{\text {model B }}^{\mathrm{H}}=\left[\begin{array}{cccccc}
454 & 142 & 142 & 0.0347 & 0.0303 & 0.116 \\
& 456 & 142 & 0.0954 & 0.00190 & 0.170 \\
& & 452 & 0.0939 & 0.0407 & 0.0458 \\
& & & 156 & 0.0563 & -0.00424 \\
& \text { Sym. } & & & 155 & 0.0450 \\
& & & & & 156
\end{array}\right]
$$

$$
E_{\text {model C }}^{\mathrm{H}}=\left[\begin{array}{ccccc}
433135134 & 0.0133 & 0.163 & -0.118 \\
436134 & 0.0401 & 0.0478 & -0.000251 \\
432 & 0.136 & 0.185 & -0.0237 \\
& & 149 & -0.0199 & -0.118 \\
\text { Sym. } & & 149 & 0.0243 \\
& & & & 150
\end{array}\right]
$$

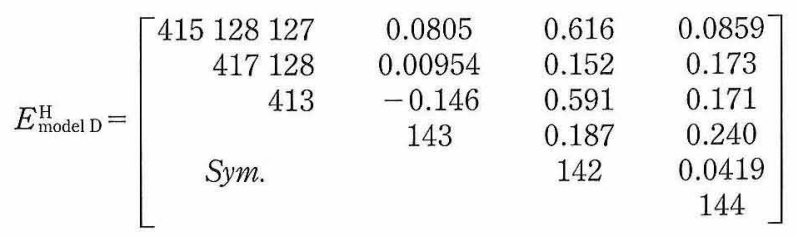

得られた弾性マトリックスを抢いて, $E^{\mathrm{H}}{ }_{11}, E^{\mathrm{H}_{22}}, E^{\mathrm{H}_{33}}, E^{\mathrm{H}}{ }_{44}$, 

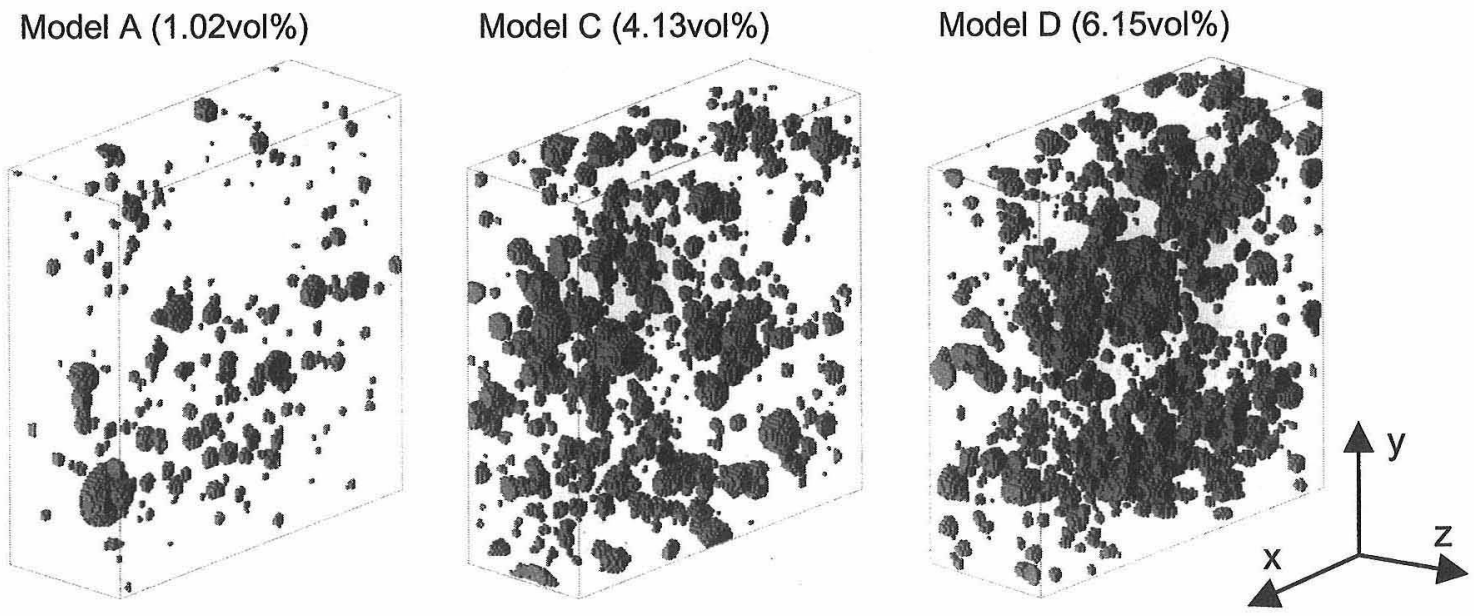

Fig. 8. Three-dimensional local models of the Sample A, C, and D. The volume of the model is $280 \times 280 \times 100 \mu \mathrm{m}^{3}$. The models are represented by voxel elements with the size of $2 \times 2 \times 2 \mu \mathrm{m}^{3}$. Only the elements of pores are shown to visualize the inside of the models. The porosity is computed from the number of elements.

Table 2. Elastic Constants of the Sample B Obtained by Various Methods

\begin{tabular}{l|c|c|c|c|c|c}
\hline \multirow{2}{*}{} & \multicolumn{3}{|c|}{ Young's moduli /GPa } & \multicolumn{3}{c}{ Poisson's ratios } \\
\cline { 2 - 7 } & $E_{\mathrm{x}}$ & $E_{\mathrm{y}}$ & $E_{\mathrm{z}}$ & $v_{\mathrm{yz}}$ & $v_{\mathrm{zx}}$ & $v_{\mathrm{xy}}$ \\
\hline Homogenization method & 387 & 388 & 385 & 0.239 & 0.238 & 0.238 \\
\hline FEM & 386 & 387 & 389 & \multicolumn{3}{c}{-} \\
\hline Experimental value & \multicolumn{3}{|c|}{387} & \multicolumn{3}{c}{0.238} \\
\hline Theoretical value & \multicolumn{3}{|c|}{387} & \multicolumn{3}{c}{-} \\
\hline
\end{tabular}

$E^{\mathrm{H}_{55}}, E^{\mathrm{H}}{ }_{66}, E^{\mathrm{H}}{ }_{12}, E^{\mathrm{H}}{ }_{13}, E^{\mathrm{H}_{23}}$ 以外の成分は, ほぼ無視でさる位 小さい値になっている.したがって，この多孔体は，モデルの $x, y, z$ のつの軸に対して，巨視的に直交異方性を有すると見 なせる.したがって, 弾性マトリックスからヤング率やポアり ン比等の工学定数を求めることが可能である.また， $E^{\mathrm{H}_{11}}$, $E^{\mathrm{H}_{22}}, E^{\mathrm{H}_{33}}$, 及び $E^{\mathrm{H}_{12}}, E^{\mathrm{H}_{13}}, E^{\mathrm{H}_{23}}$ はそれぞれほぼ等しく, $E^{\mathrm{H}}{ }_{44}$ が $\left(E^{\mathrm{H}_{11}}-E^{\mathrm{H}_{12}}\right) / 2$ にほぼ等しい，以上から，これらの アルミナ多孔体は巨視的に等方体と見なすことができる．これ は，結晶粒と球状気孔が規則性がなく分布した系の計算結果と して妥当な結果である。

Model Bについて，ヤング率とポアソン比を算出した結果 を他の方法で得た值とともに表 2 に示す．実験值は，超音波パ ルス法よって得た結果の平均值である。理論值は,

Hashin-Shtrikmanの上界を示す式16) から，気孔率を実験值の 平均である $2.28 \mathrm{vol} \%$ として算出した值である。 また，有限要 素法（FEM）の結果は，均質化法による計算に用いた同じモ デルについて，前述したように，三つの軸方向にそれぞれ強制 変位をかけて算出した結果である。均質化法や有限要素法によ るヤング率の計算值は, 直交する $x, y, z$ のつの方向のヤン グ率 $\left(E_{x}, E_{y}, E_{z}\right)$ を示している. 表 2 で示したとおり, 均質 化法によって得られた結果は，他の方法で得られた值とほぼ一 致した.

図 9 に, 気孔率に対するヤング率の值を複数の力法で求めた 結果を示した，均質化法による数值計算結果 (○印)，超音波 パルス法による実験值（印），王縮試験から求めた実験值

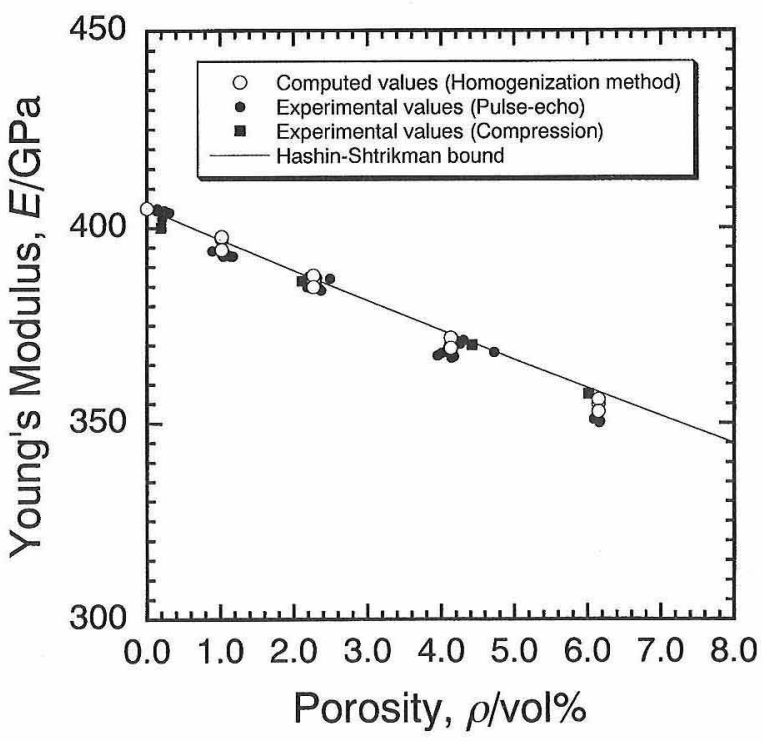

Fig. 9. Young's modulus obtained by various methods for the porous $\mathrm{Al}_{2} \mathrm{O}_{3}$ with spherical pores.

印)，及び Hashin-Shtrikmanの上界加求めた理論值（実 線）を示している。均質化法による計算值が 3 点めるが, こ れらは $E_{x}, E_{y}, E_{z}$ を示している.

本研究で用いた試料では，二つの方法で求めた実験值に有意 
な差は認められなかった。そして, 均質化法で求めた計算値 は，これらの実験値，及び理論值とほぼ一致した。

Hashin-Shtrikman の上界は, 線形弾性体, 擬等方体, 擬均 質体上見なせる二つの相からなる複合体の弾性率の上限を示す 理論式であり，球形の第二相が坬立して分散した系の弾性率を 与える。 今回扱った試料は，気孔率が低く，球状気孔がほとん ど独立に分散した系と見なせる。したがって，この前提に基づ く理論値や実験値と一致したことは, 均質化法で算出される弾 性定数が妥当なものであることを示す．

均質化法や有限要素法で算出されるヤング率は, モデルの気 孔率に依存する。本研究で用いた試料は，気孔率が小さいこと から，任意の領域においてモデルと実際の気孔率を一致させる ためには，計算機の能力を超える大きな領域をとる必要があ る. そこで，2.2節で述べたように，気孔率が実験值々一致す る $280 \times 280 \times 100 \mu \mathrm{m}^{3}$ の領域を抽出している。しかし，モデ ルの取り方による弾性率の計算結果のばらつきは, 表 2 や図 9 で示した方向によるばらつきや気孔率に対する依存性から，実 験鿁差と同程度かそれよりも小さいことが分かる。したがっ て, 今回抽出した領域は, ローカルモデルとして十分な大きさ であると判断した.

そこで, Model A〜Dの四つのローカルモデルを RVE とし て，4点曲げを模擬したグローバルストレスの計算を行った. 図10（a）に計算の概念図とともに，Model B で構成されたグ ローバルモデルに $48 \mathrm{~N}$ の荷重をかけた場合の $x$ 方向のグロー バルストレス $\left(\sigma_{x}{ }^{G}\right)$ の計算結果を示した. 本試験の場合, グ ローバルストレスが最大になる場所は, 支点間の表面近傍であ る. 支点面側で $x$ 方向にほぼ一軸の引張応力が生じ, 4 点曲げ 試験に打ける破壊強度は, 破壞時のこの部分の応力值で導かれ る. $48 \mathrm{~N}$ の荷重をかけた場合，この部分に生じる $\sigma_{x}^{\mathrm{G}}$ は約 40 $\mathrm{MPa}$ と計算された。

均質化法では，上記の計算で得た歪多をRVEに与えること によって, RVE内のローカルストレスを求めることが可能で ある. 図10（a）に示した支点間中央部のローカルモデル内の $x$ 方向の応力 $\left(\sigma_{x}^{\mathrm{L}}\right)$ 分布図を図10（b）に示した。ローカルス トレスは，ローカルモデルの表面から $10 \%$ 削った領域が表示 されている、これは，本研究のように実験的に得たロ一カルモ デルの場合，均質化法の計算で必要な周期境界に抢ける連続性 を満たしていないため，ローカルモデルの表面で特異的な值が 出る可能性があるためである. 図の外枠はローカルモデルの大

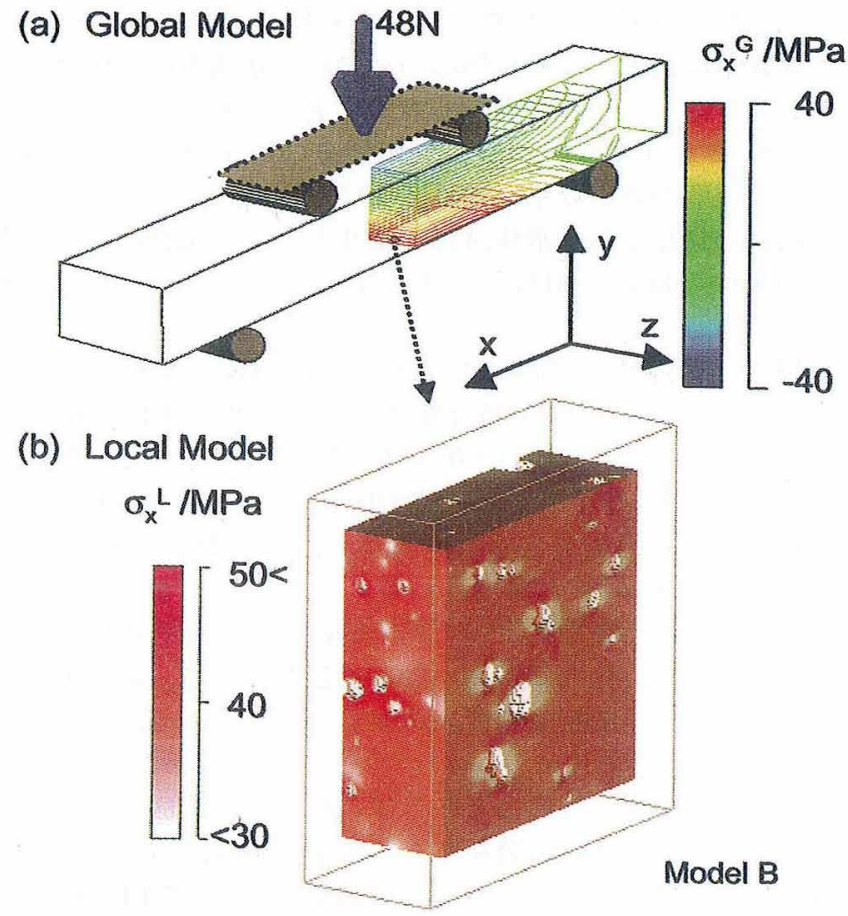

Fig. 10. Global stress, $\sigma_{x}{ }^{G}$, distribution in the global model (a) and local stress, $\sigma_{x}^{\mathrm{L}}$, distribution in the local model B (b).

\section{きさを示したものである。}

図10（b）から, 気孔の存在により応力集中が生じ, 局所的 に50 MPa 以上の応力が生じていることが分かる. 同じ荷重条 件で他の三つのモデルについて計算を行った結果を図11に示 す。気孔率が大きくなるに従って応力集中が進んでいることが 分かる、このように，均質化法を用いることによって，計算刘 象である構造体のグローバルストレスとともに，それよりもは るかに小さな不均質構造を反映したローカルストレスを構造体 の任意の部分について解析することが可能である。

\section{5. 考察}

$2 \mu \mathrm{m}$ 角のボクセル要素ごとに算出されるローカルストレス は，母相を均質体として扱って得られた結果である。実際に
Model A

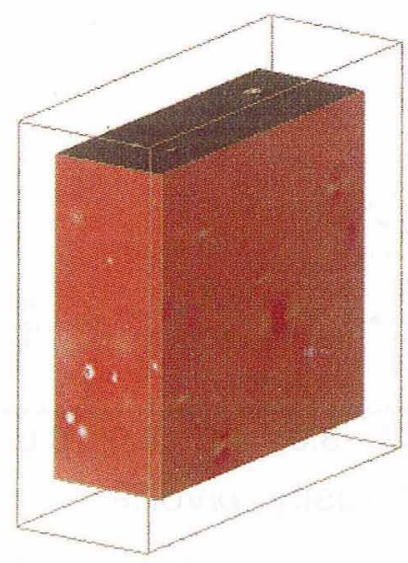

Model C

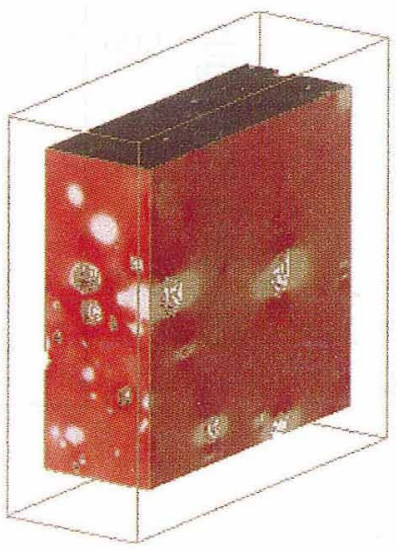

Model D

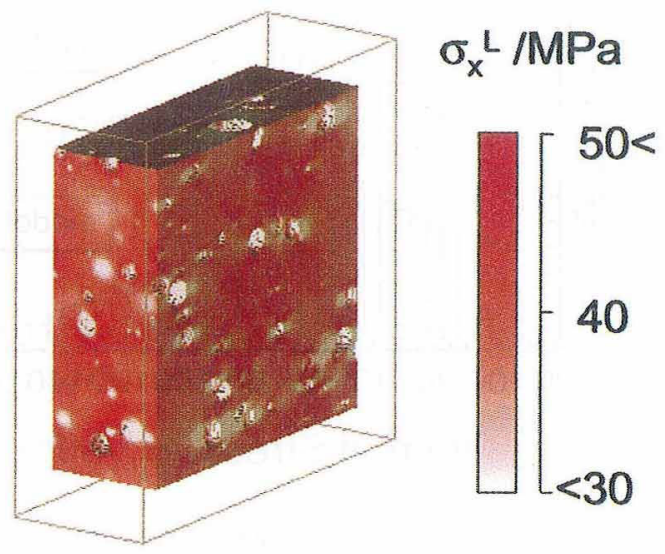

Fig. 11. Local stress, $\sigma_{x}^{\mathrm{L}}$, distribution in the local model A, C and D. The frame represents the edge of local model. 
は, 結晶粒を単位とした異方性のある粒子の集合体であるた め, 焼成時に発生する残留熱応力を含めて結晶方位に依存した 不均質性があり, 計算は真の応力値を求めるものではない。 た, 有限要素計算のための 3 次元構造のモデリングは, 図 8 に示した程度の要素分割が現段階では限界に近い。しかし，母 相が同じと見なせる緻密体試料を基準として，気孔の存在によ る応力集中の度合を相対的に比較することは可能と考えられ る.

図12は, 前述したグローバルモデルに $48 \mathrm{~N}$ の荷重を与えた 時, ローカルモデル内の98万要素のうちアルミナに対応する 要素に割り当てられたローカルストレス $\left(\sigma_{x}^{L}\right)$ を, $40 \mathrm{MPa}$

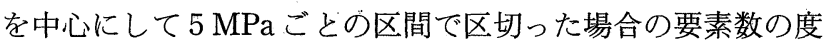
数分布を示したものである. 均質体として計算した場合， $\sigma_{x}{ }^{\mathrm{L}}$ は単一の值 $40.1 \mathrm{MPa}$ と算出される.これに対して, 気孔が存 在する場合, 応力集中によって局所的に応力の高い領域が生じ る.このように, 気孔率が高くなるにしたがって, 応力集中が 進んでいく様子が度数分布で表示することによって, より詳し く把握できる.

気孔周囲に発生する応力と多孔体の強度との関係を考える. セラミックスの強度に影響を与える因子は多数あるが，本研究 で扱っているようなセラミックス母相と気孔の 2 相の複合体 として弾性率が記述できる理想的な多孔体の場合, 気孔の存在 による応力集中が支配的な破壊因子になると考えられる.ここ では，基準試料と四つの体積率を有する多孔体が同質の母相で 構成され，同じ破壊特性を有していることを前提条件におき， ローカルストレスを破壊のパラメーターとして, 即時破壊強度 の算出を試みた.

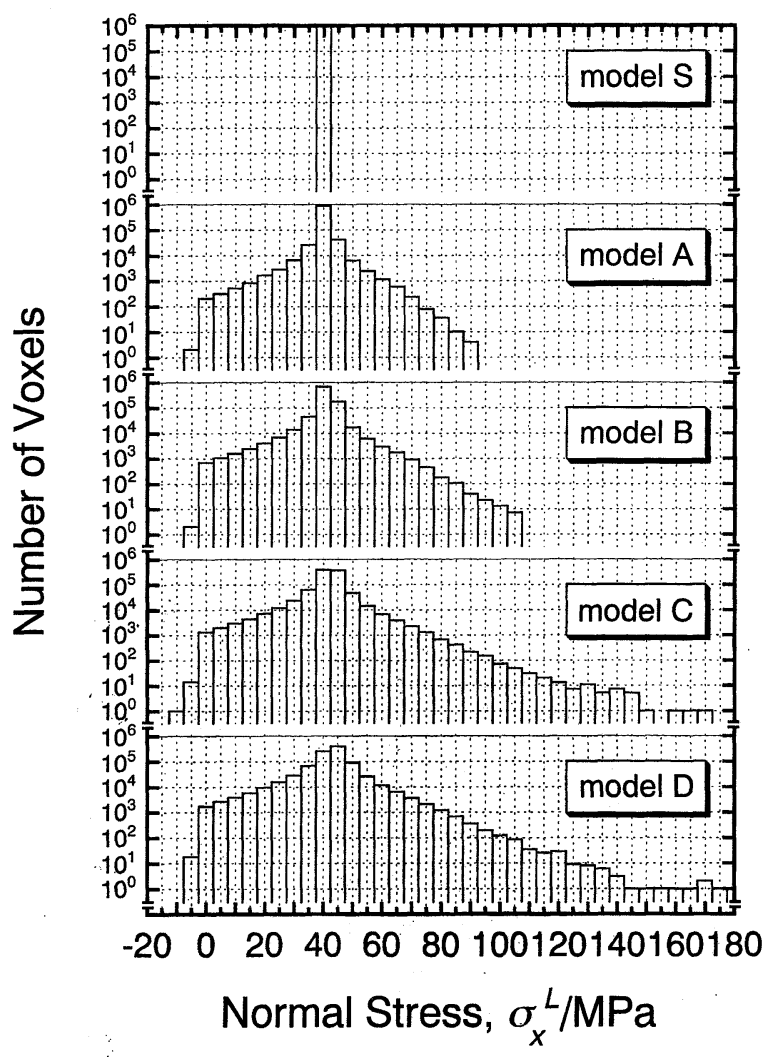

Fig. 12. Frequency distribution of local stress, $\sigma_{x}^{L}$, in local models with a volume of $280 \times 280 \times 100 \mu \mathrm{m}^{3}$. The local stress was given in each element with a volume of $2 \times 2 \times 2 \mu \mathrm{m}^{3}$. すなわち，図10（a）に示したグローバルモデルに荷重を印 加していった時, ローカルストレスの最大值が緻密体の破壊応 力に達した時の荷重を破壊荷重として強度を求めることにな る. しかし, 本研究に抢けるモデルでは, 要素数が十分でない こと等から, 最大応力値は, モデリングに起因した計算誤差を 含んでいると考えられる. 図12に示した度数分布をからも, 気孔率の高い試料では, 数個の要素が特異的に高い応力值を示 していることが分かる.このようなモデリングに起因する計算 上の誤差と考えられる因子を排除するため, 最大応力を求める ための基準值（クライテリオン）を設けることにした. クライ テリオンは基準試料である Sample S と Sample D の破壊強度 によって決定した.

通常 4 点曲げの場合, 支点中央部表面の引張方向 $(x$ 方向） の応力で破壞が起こる. したがって, ローカルストレス $\left(\sigma_{x}^{L}\right)$ と 4 点曲げ強度との関係を考える. Sample $\mathrm{S}$ の平均強度は表 1 にあるように, $536 \mathrm{MPa}$ である. 一方, Sample D の破壊強 度は273 MPa であり, Sample D に対する Sample A の強度比 は1.96である.したがって, 同じ荷重を印加した場合, Sample D には局所的に1.96倍の応力集中が生じると考え, Sample $\mathrm{D}$ の $\sigma_{x}^{\mathrm{L}}$ の最大值を Sample A と同じ荷重を印加した時の1.96 倍で定義する. Model D の度数分布から, Model A の1.96倍 の応力值を示す要素は, 応力值の高い方から数えて $0.264 \%$ の 要素であった．これよりも高い応力值を示したものは，モデリ ングに起因する計算上の誤差と考えて排除する.すなわち，上 位 $0.264 \%$ の要素が与える $\sigma_{x}^{\mathrm{L}}$ を最大応力と定義し, これをク ライテリオンとして, Model A〜Model Cの 3 点の破壊強度 を算出した。

図13は，その結果を実験結果とともに示したものである.上 述した試みは, +印で示したSample S と Sample D の実験結 果から，中間の三つ気孔率を有する多孔体の強度が内挿できる

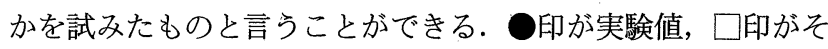
の平均値, そして○印が計算值である. 図で示したように, Model A〜Model C の破壊強度が実験結果とよく合うことが 分かった.

最大応力を決定するクライテリオンは, 気孔とボクセル要素

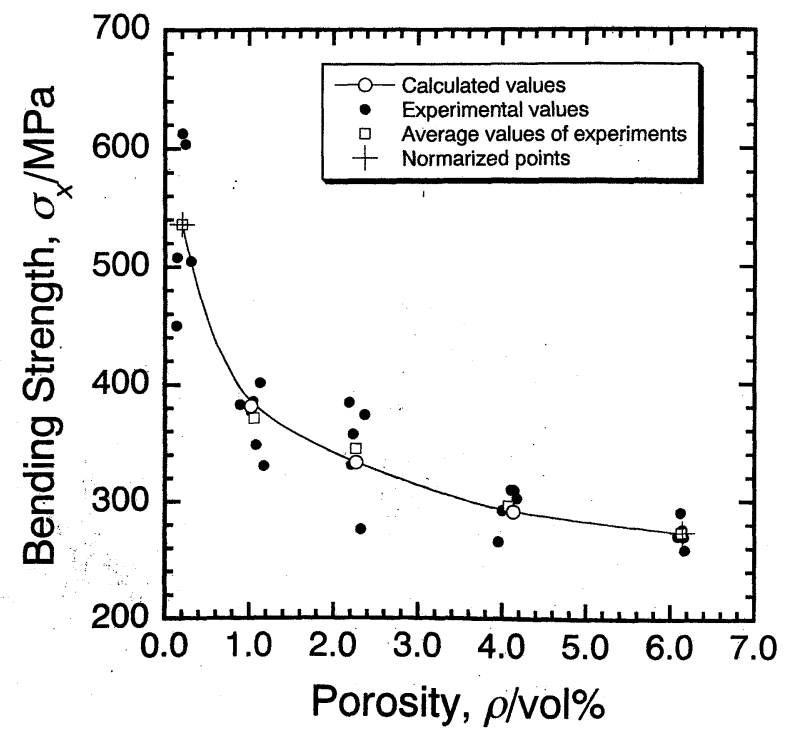

Fig 13. Four-point bending strength obtained by various methods for the porous $\mathrm{Al}_{2} \mathrm{O}_{3}$ with spherical pores. 
の相対的な大きさや気孔の形状によって異なる．十分な要素分 割ができ，気孔形態をより正確にモデリングできれば，クライ テリオンの值は小さくなっていくもの予想される.

現段階では，同じ気孔で構成される多孔体間の相対的な強度 予測に限定される. しかし，3 次元気孔形態を計算に取り込む ことで, 経験的な複合則を使わないで, 強度の気孔率に対する 依存性が算出可能であることを示した. 本研究では, 一軸応力 となる 4 点曲げ試験に対しての解析であったが, ‘von Mieses の組み合わせ応力等を導入することにより,さむざまな形状の 多孔体部材内の複雑な応力状態における強度予測に展開可能で あると考える. また， ローカルモデル内の応力分布を解析する ことによって，多孔体特有の損傷挙動を扱うことも可能になる ものと考える.

\section{6. 総 括}

イメージベースモデリングにより，セラミックス多孔体の 3 次元気孔形態のモデルリングを行い, 均質化法で弾性解析を行 うシステムを構築した. システムの検証を目的として, 独立し た球状気孔を有する単純なアルミナ多孔体を作製し，モデリン グと弾性解析を行った. 均質化法で得た弾性マトリックスから 算出したヤング率は, 理論値, 実験値, 及び有限要素法による 計算結果と一致した. 更に, 4 点曲げ試験を模擬して, 曲げ試 験片内に生じる大域応力と局所応力の計算を行った. 要素単位 で計算される局所応力值を解析することにより, 気孔周囲に発 生する応力集中の状態の可視化や解析が可能であることを示し た.

この方法の利点は，イメージベースモデリングを採用してい ることにより, 複合則で扱うことができない複雑な気孔形態を 扱うことができる点，そして均質化法を採用していることによ り，扱う気孔の大きさよりはるかに大きな部材の任意の部分に ついて, 気孔形態を反映した解析が可能である点である. 熱解 析やガスの透過特性等の流体解析との連成解析への拡張も可能 である. 今後, 計算機の発達とともに, 材料や部材解析の有力 な解析手法に発展するものと期待できる.

そのためには, 計算科学からのアプローチに加えて, 材料科 学の立場からの検証やニーズの掘り起こしが必要である. 次の ステップとして, 技術の汎用化の視点から, 気孔率の高い複雑 な気孔形態や複雑な部材形状への適用を試みる予定である.
謝辞本研究は経済産業省産業技術環境局が推進する産業 技術基盤研究開発プロシェェクト「シナジーセラミックスの研究開 発」の一環として, ファインセラミックス技術研究組合が新エネ ルギー・産業技術総合開発機構より委託を受け, シナジーセラ ミックス研究体に所属する著者らによって行われたものである. 著者の木村圭一, 小川秋水, 河本 洋は, シナジーセラミックス 研究体に所属している.

また，試料研削による 3 次元気孔形態のデータ取得に当たり， 株式会社サートンワークスにご協力を頂いた。ここに謝意を表し ます。

(2001年 8 月日本機械学会材料力学部門講演会発表)

(2001年 9 月日本セラミックス協会第14回秋季シンポジウム講 演会発表)

\section{文 献}

1) Coble, R. L. and Kingery, W. D., J. Am. Ceram. Soc., 39, 377-85 (1956).

2) Mackenzie, J. K., Proceedings of the Physical Society of London, 63B, 2-11 (1950).

3) Schreiber, E., J. Am. Ceram. Soc., 51, 541-42 (1968).

4) Berryman, J. G., J. Energ. Resour. Technol., 116, 87-96 (1994).

5) Takano, N., Zako, M. and Kimura, K., Mater. Sci. Res. Int., STP-2, 66-71 (2001).

6) Roberts, A. P. and Garboczi, E. J., J. Am. Ceram. Soc., 83, 3041-48 (2000).

7) Matsubara, H., SUT Bulletin, 15, 12-20 (1998) [in Japanese].

8) Nakamura, M. and Ohnishi, T., J. Ceram. Soc. Japan, 101, 1175-79 (1993) [in Japanese].

9) Hollister, S. J. and Riemer, B. A., Mathematical Methods in Medical Imaging II, 2035, 94-106 (1993).

10) Adachi, T., Tsubota, K. and Tomita, Y., Trans. Jpn. Soc. Mech. Eng., 66, 1640-47 (2000) [in Japanese].

11) Nagai, G., Yamada, T. and Wada, A., J. Struct. Constr. Eng., 509, 77-82 (1998) [in Japanese].

12) Lions, J. L., "Some Methods in the Mathematical Analysis of Systems and Their Control," Science Press (1981).

13) Sanchez-Palencia, E., "Non-homogeneous Media and Vibration Theory," Springer-Verlag (1980).

14) Guedes, J. M. and Kikuchi, N., Comput. Methods Appl. Mech. Eng., 83, 143-98 (1990).

15) Takano, N., Zako, M., Uetsuji, Y. and Kashiwagi, Y., Trans. Jpn. Soc. Mech. Eng., 63, 152-58 (1997) [in Japanese].

16) Edited by the Chemical Society of Japan, "Kagaku-Binran Kiso-Hen," Maruzen (1993) pp. II-25, (ISBN 4-621-038702 C3043) [in Japanese].

17) Hashin, Z. and Shtrikman, S., J. Mech. Phys. Solids, 11, 127-40 (1963). 